\title{
Treatment of gonorrhoea with procaine penicillin plus probenecid
}

\author{
J. LESIŃSKI, D. DZIERZANOWSKA, M. SZYMCZAK, H. LINDA, \\ C. WISNIEWSKA, A. NAWARA, AND A. WINOGRODZKA \\ From the Departmental Polyclinic of Dermatology and Venereology and the Institute of Microbiology, \\ Medical School, Bialystok, Poland
}

The decrease in the sensitivity of gonococci to penicillin has made it essential to devise new methods of treating gonorrhoea.

Since 1954 a steady rise in the percentage of strains with a lowered sensitivity to penicillin has been observed in the U.S.A. (Thayer, Field, Magnuson, and Garson, 1957) and in Europe (Reyn, Korner, and Bentzon, 1958), and the degree of this reduced sensitivity to penicillin has also increased, being fifteen times higher in the U.S.A. in 1964 than in 1965 (Willcox, 1968).

As shown by the investigations of Smith and Levey (1967), Ho and Chang (1967), and Reyn (1968), and by the review of Willcox (1970), the fall in sensitivity was most marked in the Far Eastern countries. Reyn (1971) showed that the minimum inhibitory concentration (MIC) of certain Far Eastern strains was $6 \mathrm{u} . / \mathrm{ml}$.; she also reported a marked degree of partial resistance of gonococcal strains isolated in the Mediterranean countries and Denmark.

In recent years an appreciable reduction in the number of gonococcal strains sensitive to penicillin has been noted in Poland. Kilczewski (1964) found that in Bialystok, a mainly agricultural Province, only 9 per cent. of strains had reduced sensitivity, but 7 years later 48 per cent. of strains were found to be partially resistant (Kilczewski, 1971). The degree of resistance depended, in Poland as elsewhere, on the type of population investigated. In the rural areas of Bialystok Province the MIC did not as a rule exceed $1 \mathrm{u} . / \mathrm{ml}$. (Kilczewski, 1971), whereas in the ports of Gdansk and Gdynia it reached several units per ml. (Bowszyc, Wiewiorkowska, Filipiuk, and Dratwinski, 1971). Similar data were given by Wolska (1971) in her investigations in the capital city of Warsaw.

Despite this considerable fall in penicillin sensitivity, the majority of workers still consider penicillin to be the standard treatment for gonorrhoea (WHO

Received for publication October 19, 1972

Address: Prof. J. Lesinski, Departmental Polyclinic of Dermatology and Venereology, Manifestu, Lipcowego 3, Bialystock, Poland
Expert Committee, 1963). Present day treatment aims at achieving a serum penicillin level which exceeds, for at least a few hours, the MICs of those gonococcal strains which have a marked partial resistance to penicillin.

The trials of Jensen, Kvorning, and Nørredam (1963), Holmes, Johnson, and Floyd (1967), Schmidt and Roholt (1965), and Olsen and Lomholt (1969) showed that treatment with penicillin $G$ combined with oral probenecid gives satisfactory results even in those parts of the world where the percentage of less sensitive strains is high. Investigations carried out on the serum penicillin concentration of patients undergoing combined penicillin and probenecid treatment (White, Conch, Foster, Galloway, Hunter, and Knight, 1965; Evans, 1966; Schmidt and Roholt, 1965; Cornelius, Schroeter, Lester, and Martin, 1971) have given varying results, probably because of differences in the methods used in combining probenecid with penicillin and the use of different types of penicillin.

The investigations presented in this paper were undertaken to devise schedules for combined penicillin and probenecid treatment which would absolutely ensure that the antibiotic level in the patient's serum exceeded by a wide margin the level necessary for inhibition of those strains of gonococci which had been found in Poland to have the highest partial resistance to penicillin.

\section{Material and methods}

A total of 372 patients was treated with two combined treatment schedules.

I. The 72 patients ( 50 men and 22 women) treated according to Schedule I received two intramuscular injections of 2.4 m.u. aqueous procaine penicillin $G$ (produced by Polfa, Tarchomin, Warsaw) at an interval of $24 \mathrm{hrs} ; 45$ minutes before each penicillin injection each patient was given an oral dose of $1 \mathrm{~g}$. probenecid (Benemid, produced by Jugolek, Zagrzeb).

II. The 300 patients ( 220 men and 80 women) treated according to Schedule II received a single injection of $4.8 \mathrm{~m}$.u. procaine penicillin $\mathbf{4 5}$ minutes after an oral dose of $1 \mathrm{~g}$. probenecid. 
Determination of serum penicillin levels

The serum penicillin levels of fourteen patients treated by Schedule I and of seven patients treated by Schedule II were determined in samples taken 3 to $48 \mathrm{hrs}$ after the first injection. The method used was that of Chabert and Baulinger (1957).

\section{Bacteriological tests}

In all the patients, bacteriological diagnosis was made by the direct microscopical examination of smears and by cultures. The latter were made on a modified Roiron medium used for many years at the Bialystok Research and Diagnostic Centre for Venereal Diseases (Kilczewski, 1964). In a group of sixty patients chosen at random, the penicillin sensitivity of the strain isolated before treatment was determined.

All the patients had further examinations during the 10 days after treatment when, in addition to clinical examinations, direct microscopic examination of smears and cultures were carried out twice. Cultures were also taken in most of the female patients after the first menstruation subsequent to treatment.

Re-infection was considered to have occurred in those patients in whom the tests were negative in the 10-day period after treatment, but who subsequently had a recurrence of gonorrhoea. A diagnosis of re-infection was made only in those cases in which the patient had had intercourse after treatment with a partner who was infected with gonorrhoea or who was strongly suspected of having gonorrhoea on the basis of epidemiological evidence. All other cases were considered to be treatment failures.

\section{Results}

The Table shows the results of treating 72 patients according to Schedule I. Two, both women, failed to respond, giving a failure rate of 2.7 per cent. In two other cases re-infection occurred.

The Table also shows the results of treating 300 patients according to Schedule II. Only two $(0.66$ per cent.) failed to respond. One of these patients, a male, had a congenital abnormality of the urethra. Re-infection occurred in seven cases ( $2 \cdot 3$ per cent.).
The results of the serum penicillin level determinations are shown in the Figure.

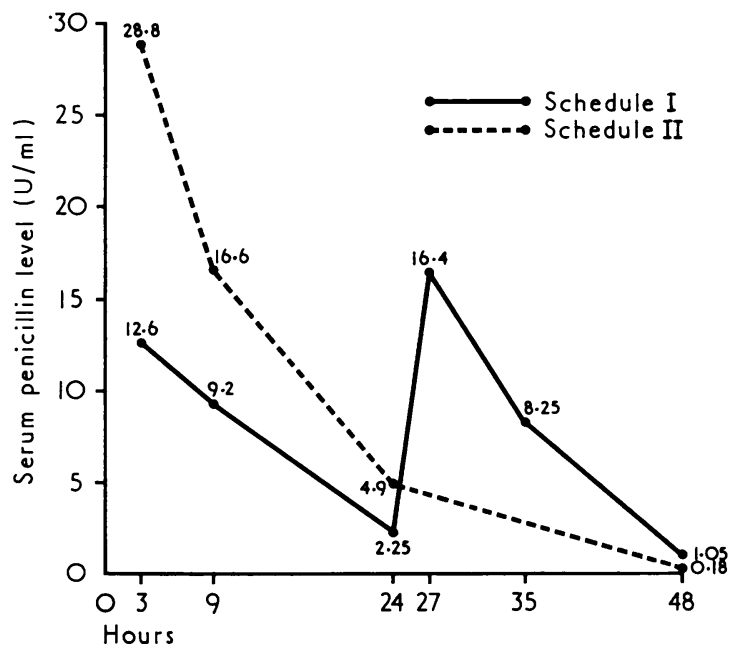

FIGURE Mean serum levels of penicillin in patients treated with procaine penicillin plus probenecid

Schedule I $2 \times 2.4$ m.u. +1 g. probenecid

Schedule II 4.8 m.u. +1g. probenecid

\section{Schedule I}

The mean penicillin level was $12.6 \mathrm{u} . / \mathrm{ml} .3 \mathrm{hrs}$ after the first injection and $9 \cdot 2 \mathrm{u} . / \mathrm{ml} .9 \mathrm{hrs}$ after. $3 \mathrm{hrs}$ after the second injection, the mean serum level was $16.4 \mathrm{u} . / \mathrm{ml}$. and $9 \mathrm{hrs}$ after $8.25 \mathrm{u} . / \mathrm{ml} .48 \mathrm{hrs}$ after treatment commenced, a mean serum penicillin level of $1.05 \mathrm{u} . / \mathrm{ml}$. was noted. In the sera investigated, considerable individual variations in the antibiotic concentration were observed, but the penicillin concentration exceeded $3 \mathrm{u} . / \mathrm{ml}$. for a period of $9 \mathrm{hrs}$ in every patient but one.

\section{Schedule II}

The mean pencillin level was $28 \cdot 8 \mathrm{u} . / \mathrm{ml} .3 \mathrm{hrs}$ after the injection, $16.6 \mathrm{u} . / \mathrm{ml}$. $9 \mathrm{hrs}$ after, $4.9 \mathrm{u} . / \mathrm{ml}$.

TABLE Results of combined procaine penicillin and probenecid treatment of gonorrhoea

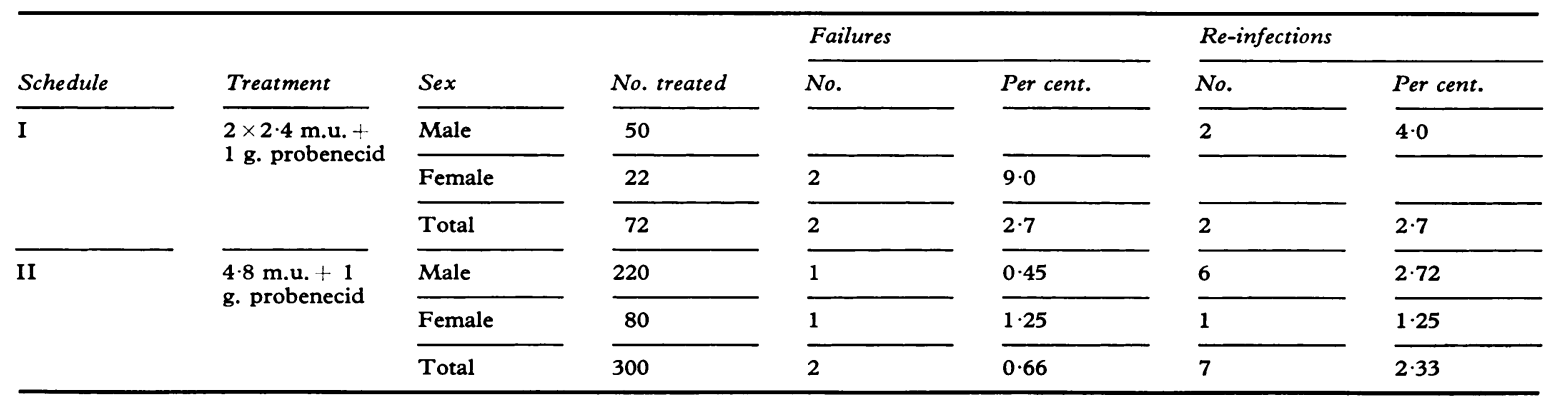


$24 \mathrm{hrs}$ after, and only $0.18 \mathrm{u} . / \mathrm{ml}$. $48 \mathrm{hrs}$ after. In these patients too, considerable individual variations in the penicillin levels were observed. In all the patients treated by Schedule II, the serum penicillin levels were several times higher than the MIC for gonococcal strains observed in Poland.

Sensitivity determinations on gonococcal strains isolated from a randomly chosen group of sixty patients revealed reduced penicillin sensitivity (MIC of $0.125 \mathrm{u} . / \mathrm{ml}$. or greater) in 32 persons (53 per cent.). The MIC did not, however, exceed $1 \mathrm{u} . / \mathrm{ml}$. in any of the cases investigated.

The treatment was well tolerated and no serious side-effects were observed in any of the 372 patients.

\section{Discussion}

The serum level estimations showed that both schedules achieved antibiotic concentrations of over $3 \mathrm{u} . / \mathrm{ml}$. for over $9 \mathrm{hrs}$. This is the concentration necessary for inhibition of growth in vitro of those gonococcal strains observed in Poland to have the lowest degree of penicillin sensitivity (Bowszyc and others, 1971). All the patients treated according to Schedule II were found to have a penicillin serum level several times higher than the highest MIC observed in Poland, giving a very wide margin of safety. Such a margin is necessary because of the individual variations in serum penicillin levels observed in our investigations and because of the present tendency in Poland to a further rise in the degree of partial resistance of gonococcal strains to penicillin.

In judging the results of treatment, it should be emphasized that, although 53 per cent. of the gonococcal strains in our series had a lower sensitivity to penicillin, the degree of this partial resistance was comparatively low and no strain required a MIC in excess of $1 \mathrm{u} . / \mathrm{ml}$.

Although the overall results with Schedule I were good, the two treatment failures both occurred in females in whom the failure rate was therefore 9 per cent.; the results are usually worse in females, as has been demonstrated by the investigations of Polish workers presented in a monograph by Miedzinski (1970).

In the 300 patients treated according to Schedule II ( $4.8 \mathrm{~m}$.u. procaine penicillin intramuscularly plus 1 g. probenecid by mouth), the failure rate was only 0.66 per cent. ( 1.25 per cent. in females). This schedule would seem to be the treatment of choice.

\section{Summary}

Two schedules were assessed for the treatment of gonorrhoea. 72 patients were given two injections of $2.4 \mathrm{~m}$.u. procaine penicillin intramuscularly at an interval of $24 \mathrm{hrs}$, each injection being preceded by an oral dose of $1 \mathrm{~g}$. probenecid. The failure rate was 2.7 per cent. 300 patients were given a single injection of $4.8 \mathrm{~m}$.u. procaine penicillin preceded by an oral dose of $1 \mathrm{~g}$. probenecid. The failure rate was 0.66 per cent.

In the group given two injections, the mean serum level of penicillin was $12.6 \mathrm{u} . / \mathrm{ml}$. $3 \mathrm{hrs}$ after the first injection and $9.2 \mathrm{u} . / \mathrm{ml} .9 \mathrm{hrs}$ after; it was 16.4 u. $/ \mathrm{ml}$. $3 \mathrm{hrs}$ after the second injection and 8.25 u. $/ \mathrm{ml} .9 \mathrm{hrs}$ after. In those given the single injection, the mean serum level of penicillin was $28.8 \mathrm{u}$. $/ \mathrm{ml}$. $3 \mathrm{hrs}$ after the injection and $16.6 \mathrm{u} . / \mathrm{ml} .9 \mathrm{hrs}$ after.

Considerable individual variation in serum penicillin levels was noted in both groups.

\section{References}

Bowszyc, J., Wiewiórkowska, L., Filipiuk, J., and Dratwiński, Z. (1971) Przegl. Derm., 58, 715

ChabBert, J., and Boulingre, H. (1957) Rev. frans. Ét. clin. Biol., 2, 639

Cornelius III, C. E., Schroeter, A. L., Lester, A., and MARTIN, J. E. (1971) Brit. F. vener. Dis., 47, 359

Evans, A. J. (1966) Ibid., 42, 251

Holmes, K. K., Johnson, D. W., and Floyd, T. M. (1967) f. Amer. med. Ass., 202, 461

Ho, Ting-JaO, and Chang, Shurh-Shen (1967) Far East med. F., 3, 320

Jensen, P. E., Kvorning, S. A., and Nørredam, K. (1963) Brit. F. vener. Dis., 39, 238

KILCZEWSKI, W. (1964) Dissertation presented to Medical High School at Białystok

- (1971) Personal communication

MiedzIŃSKI, F. (1968) 'Współczesne Leczenie Chorób Wenerycznych'. PZWL Edition, Warsaw

Olsen, G. A., and Lomholt, G. (1969) Brit. f. vener. Dis., 45, 144

REYN, A. (1968) Unpublished material from WHO Neisseria Centre, Copenhagen

- (1971) WHO/VDT/RES/GON/56.71

-, KorNer, B., and Bentzon, M. W. (1958) Brit. F. vener. Dis., 34, 227

Schмidt, H., and Rоноцт, K. (1965) Ugeskr. Laeg., 127, 478

Smith, D. D., and Levey, J. M. (1967) Med. f. Aust., 1, 849

Thayer, J. D., Field, F. W., Magnuson, H. J., and Garson, W. (1957) Antibiot. and Chemother., 7, 306

Willcox, R. R. (1968) In 'Antibiotic Treatment of Venereal Diseases', ed. A. Luger, p. 101 (Curr. Probl. Derm., vol. 2). Karger, Basel

- (1970) Brit. F. vener. Dis., 46, 217

WolsKa, H. (1971) Personal communication

White, A. C., Couch, R. A., Foster, F., Calloway, S., HuNTER, W., and KNIGHT, V. (1956) 'Antibiotics Annual 1955-56', p. 490

WHO (1963) Expert Committee on Gonococcal Infections: First Report. WHO Tech. Rep. Ser. No. 262 
Traitement de la gonococcie par procainepénicilline plus probénécide

\section{SOMMAIRE}

Deux schémas furent essayés dans le traitement de la gonococcie. 72 malades reçurent 2 injections intramusculaires de 2,4 m.u. de pénicilline-procaïne séparées par un intervalle de 24 heures. Une dose orale de $1 \mathrm{~g}$. de probénécide fut donnée avant chaque injection. Le taux d'échec fut de 2,7 pour cent. 300 malades reçurent une seule injection de $4,8 \mathrm{~m}$.u. de procaine-pénicilline précédée par une dose orale de $1 \mathrm{~g}$. de probénécide. Le taux d'échec fut de 0,66 pour cent.

Dans le groupe recevant deux injections, le taux sérique moyen de pénicilline fut de $12,6 \mathrm{u} / \mathrm{ml}$. trois heures après la première injection et de $9,2 \mathrm{u} / \mathrm{ml}$. à la neuvième heure; aprés la deuxième injection, ce taux fut de 16,4 $\mathrm{u} / \mathrm{ml}$. à la troisième heure et de $9,2 \mathrm{u} / \mathrm{ml}$. à la neuvième heure. Dans le groupe ayant eu une seule injection, le taux sérique moyen de pénicilline fut de $28,8 \mathrm{u} / \mathrm{ml}$. 3 heures après l'injection et de $16,6 \mathrm{u} / \mathrm{ml}$. à la neuvième heure.

Dans les deux groupes on observa des variations individuelles considérables dans les taux sériques de pénicilline. 